\title{
Translanguaging and Disciplinary Language in the Individual, at School and in Society
}

\section{Gudrun Svensson och Ann-Christin Torpsten}

The present thematic issue draws on translanguaging and disciplinary language from seven studies that link to international contexts of language use, namely, to the countries of Cyprus, Estonia, Pakistan and Sweden. It spans different home environments as well as a variety of school stages from pre-school class to university and adult education. The different perspectives relate, for example, to mothers' concern to maintain their children's mother tongue, teachers' concern to implement and apply translanguaging and students' concern about multilingual education. Other perspectives refer to language use and language norms in subjects, school and society. These articles reflect today's society with its imprint of globalization and multiculturalism and are all varieties under the umbrella concept of translanguaging. The first six articles offer a spectrum of empirical studies related to translanguaging while the last one has a theoretical profile on disciplinary language training.

The concept translanguaging stems from the word trawsetietu in Welsh and was coined by the researcher Cen Williams (1994, 1996) who framed a practical school research where emerging bilinguals alternated between two learning languages, the Welsh mother tongue and English the school language. His research followed a vein of previous bilingual studies, for instance Cummins's (1976) hypothesis about CUP, common underlying proficiency, and Grosjean's (1982) proposition that the bilingual is not the same as two monolinguals in one person.

Later the term was translated into English as translanguaging (Baker 2001), which is now the designation of a concept with a variety of perspectives on the use of multilingual resources. García (2009: 44) defined translanguaging as "engaging in bilingual or multilingual discourse" while Baker (2011: 288) characterized it as " the process of making meaning, shaping experiences, gaining understanding and knowledge through the use of two languages". Though the concept of translanguaging has a widespread application, the original educational purport is still of significant dominance in the field (to mention a few recent publications in an extensive research field. ${ }^{1}$ The dominance of research on translanguaging in education is also

\footnotetext{
1 Axelsson 2015; Conteh \& Meyer 2014; Creese \& Blackledge 2010; Cummins \& Early 2011; Cummins \& Persad 2014; García \& Kleyn 2016; García \& Wei 201; Hornberger \& Link 2012; Lewis, Jones \& Baker 2012; Little \& Kirwan 2018; Menken \& Sanchez 2019; Paulsrud et al. 2018; Reath Warren 2017; Schröder 2012; Svensson 2017; Svensson \& Torpsten 2017; Torpsten \& Svensson 2017;)
} 
reflected in the present issue where a majority of the articles relate to school settings.

Williams' translanguaging model had a strictly regulated design of alternating between Welsh and English in education. However, the educational vein of translanguaging has turned into broader accommodations and for instance implicates research on teachers' approach to teaching, pupils' identity development and teaching materials (Cummins \& Early 2011; Conteh \& Meier 2014; García 2009; Hornberger \& Link 2012; Svensson 2017). Baker (2001/2011) emphasizes tranlanguaging as a dynamic bilingual resource where students can apply both their languages functionally to develop communicative and cognitive abilities. Other researchers highlight that the application of translanguaging in the classroom creates an intercultural awareness within the students which is of great importance for appreciation and equality in a diverse society (Hornberger 2004; Jørgensen 2008).

The translingual and multilingual perspective can be related to the disciplinary language in different school subjects, as second language learners benefit from participating in teaching practices where the disciplinary content and relevant linguistic resources are taught in parallel (Schleppegrell 2004; Fang \& Schleppegrell 2008).

\section{The content of the issue}

The authors of the current publication all participated in the conference Translanguaging in the Individual, at School and in Society at Linnaeus University at Växjö campus in Sweden in April 2019, and ten of them gave presentations of their research. The issue contains three articles in English and four in Swedish.

The first article, Family language policy leading to multilingual home literacy environment: Evidence from interviews with Russian-speaking mothers in Cyprus, Estonia and Sweden by Sviatlana Karpava, Natalia Ringblom \& Anastassia Zabrodskaja, investigates family language policies which lead to an environment of multilingual home literacy. The article is based on interviews with Russian-speaking women from Russian- and majoritylanguage-speaking families in Cyprus, Estonia and Sweden. The investigation demonstrates how translanguaging, extralinguistic and sociolinguistic factors affect the development of home language literacies among children in immigrant and minority settings. The parents in all three countries realized the importance of early childhood literacy experiences at home and tried to enhance these experiences both in Russian and in the majority language of the country via (in)direct teaching and meaning-focused shared activities. Translanguaging was used in multiple language learning processes, and was at home often a reflection of translanguaging in the society. The parents implemented translanguaging strategies in order to increase their children's 
educational opportunities and improve their chances for rewarding careers and comfortable lives.

The second article, Möjligheter och utmaningar - lärares uppfattningar om flerspråkighet och transspråkande [Possibilities and challenges - teachers' perceptions of multilingualism and translanguaging] by Gudrun Svensson, is also based on interviews and focuses on the implementation of translanguaging in a primary and intermediate school. The article proceeds from a longitudinal study with phenomenographic analyses (Marton \& Svensson 1978) and points out the teachers' perceptions that they found it advantageous to use translanguaging strategies in their multilingual classrooms, but also encountered difficulties in implementing an until then unknown educational paradigm in a monolingual environment. The study reveals that the implementation through time resulted in overall changes of attitudes towards the use of multilingual resources in education. During the implementation time the search for support and increase of knowledge created progressive collaborative teacher work inside the school and later on a further distribution of the translanguaging paradigm to other schools.

In the third article, Translanguaging and multilingual teaching and writing practices in a Pakistani university: Pedagogical implications for students and faculty by Muhammad Shaban Rafi and Rebecca Fox, perceptions of language use in education are also in focus. The aim of the study is to reveal challenges faced by the English faculty and find solutions by exploring aspects of teaching and learning English in classes with multilingual learners from different areas in Pakistan. The study is based on surveys and interviews with students and teachers and written texts by the students. Results from the investigation point to multiple possibilities for applying translanguaging practices to become a natural part in higher education in bi/multilingual contexts. Translanguaging could be a viable approach to engage multilingual learners in their learning and help close the gap between the multilingual students' first language repertoires and their English learning. Drawing on their first language, translanguaging approaches could support more precise communication about content and help students gain knowledge.

Article four, Då, nu och sen - nyanlända elever $i$ gymnasieskolans Introduktionsprogram [Then, now and afterwards - newly arrived students in high school introductory programme] by Jan Berggren and Ann-Christin Torpsten, is the first classroom study on this issue. The article contains the stories of newly arrived young people and their teachers in the language introduction programme about multilingual teaching of translanguaging in the subjects of science and civics. Interviews form the basis for analyses of the students' and teachers' attitudes towards the young people's previous knowledge, continued learning and the challenges facing young people when 
they reach upper secondary school eligibility try to fulfil their future dreams. The investigation shows the importance of working for social justice to ensure that all languages and all knowledge are essential and useful for further learning in the courses they lead.

Article five, Transspråkande $i$ en flerspråkig förskoleklass [Translanguaging in a multilingual pre-school class] by Manuel Lupsa, is also a classroom study, investigating when and how languages other than the language of instruction, in this case Swedish, are used as a resource for learning in the preschool class. The teacher in the study has a Swedish background and Swedish as a mother tongue, while all the students, except one, have a mother tongue other than Swedish. The study shows that translanguaging in teaching consists of both practice and strategy in interaction and that the individual teacher must have strategies to be able to work with translanguaging in the daily school work. The present study also shows that translanguaging practice in multilingual groups can be both student- and teacher-initiated and that it also arises spontaneously in the interaction in the form of free contributions. However, the study shows that the existence of students' free contributions requires sensitivity on the part of the teacher.

Article six, Verbaliserade och praktiserade språknormer - Transspråkande pedagogik inom Svenska för invandrare [Verbalized and practised language norms - Translanguaging pedagogy in Swedish for immigrants] by Annika Norlund Shaswar, contributes to the understanding of the conditions for pedagogical translanguaging by examining an SFI teacher's verbally expressed and practised language norms for not yet functionally literate adult second-language learners. The study has as its starting point Jørgensen's (2008) statement that people's linguistic behaviour is based on four different language norms. When examining the teacher's opinions on teaching multilingual students and educational interaction the investigation shows that the teacher alternates between constructing both a monolingual and an integrated multi-lingual and polylingual norm. The alternation seems to aim at strengthening a social relationship between the teacher and the students, and it also has a didactic purpose. With regard to the preconditions for developing a translanguaging pedagogy within SFI teaching at the starting level, the study shows that there seem to be several significant obstacles.

Article seven, Disciplinary language - a question of content, voices and structures in content-area texts, by Ewa Bergh Nestlog deals with disciplinary language as a key concept that can be applied when studying teaching practices in different school subjects. The study is directed towards theoretical perspectives, and models for analysis of disciplinary language and instructional practices are presented. Being based on a dialogical perspective and systemic functional linguistics, the analytical tools presented draw 
attention to disciplinary content, disciplinary voices and language and resource structures relevant to the discipline as three aspects of content-area texts and disciplinary language. Furthermore, content knowledge, voices and structures are three corresponding aspects of the instructional practice in all content areas. In the article the concept of translanguaging is not used, but the models can support the understanding of multilingual and translingual classroom settings, as the categories mentioned above can be applied in relation to the students' first language as well as their additional languages.

\section{References}

Axelsson, Monica (2015), "Flerspråkiga barn utvecklar litteracitet" [Multilingual children develop literacy], in Helle Pia Laursen (ed.), Litteracitet och språklig mångfald [Literacy and linguistic diversity] Lund: Studentlitteratur, pp. 307-336.

Baker, C. (2001), The Foundations of Bilingual Education and Bilingualism. 3rd edition. Clevedon, UK: Multilingual Matters.

Baker, C. (2011), The foundations of Bilingual Education and Bilingualism. 5th edition. Bristol, UK: Multilingual Matters.

Conteh, Jean \& Meier, Gabriela (eds) (2014), The Multilingual Turn in Languages Education: Opportunities and Challenges. Bristol/Buffalo/Toronto: Multilingual Matters.

Creese, Angela \& Blackledge, Adrian (2010), "Translanguaging in the bilingual classroom: A pedagogy for learning and teaching", The Modern Language Journal, 94 (1): 103-115.

Cummins, Jim (1976), The Influence of Bilingualism on Cognitive Growth: A Synthesis of Research Findings and Explanatory Hypothesis. Working Papers on Bilingualism. Ontario: Institute for Studies in Education.

Cummins, Jim and Early, Margret (2011), Identity Texts: The Collaborative Creation of Power in Multilingual Schools. Stoke on Trent: Trentham Books.

Cummins, Jim \& Persad, Robin (2014), "Teaching through a multilingual lens: The evolution of EAL policy and practice in Canada", Education Matters, 2(1): 3-40.

Fang, Zhihui \& Schleppegrell, Mary J. (2008), Reading in Secondary ContentAreas. Ann Arbor: University of Michigan Press.

García, Ofélia (2009), Bilingual Education in the 21st Century: A Global Perspective. Malden: Blackwell Publ.

García, Ofélia and Kleyn, Tatyana (eds) (2016), Translanguaging with Multilingual Students: Learning from Classroom Moments. New York, NY: Routledge.

García, Ofélia \& Wei, Li (2014). Translanguaging: Language, Bilingualism and Education. New York: Palgrave Macmillan.

Grosjean, François (1982), Life with Two Languages - An Introduction to Bilingualism. Cambridge, Mass.: Harvard Univ. Press. 
Hornberger, Nancy H. and Link, Holy (2012), Translanguaging and Transnational Literacies in Multilingual Classrooms: A Biliteracy Lens. Philadelphia: Graduate School of Education, University of Pennsylvania.

Hornberger, Nancy H. (2004), "The continua of biliteracy and the bilingual educator: Educational linguistics in practice", International Journal of Bilingual Education and Bilingualism, 7 N, 2 \& 3: 155-171.

Jørgensen, J. Normann (2008), "Polylingual languaging around and among children and adolescents", International Journal of Multilingualism, 5(3: 161-176.

Lewis, Gwyn, Jones, Bryn \& Baker, Colin (2012), “Translanguaging: Origins and development from school to street and beyond", Educational Research and Evaluation, 18(7), 641-654.

Little, David and Kirwan Déirdre (2018), "Translanguaging as a key to educational success: The experience of one Irish primary school", in Piet Van Avermaet, Stef Slembrouck, Koen Van Gorp, Sven Sierens \& Katrijn Maryns (eds), The Multilingual Edge of Education. Basingstoke: Palgrave Macmillan, pp. 313-339.

Marton, Ference \& Svensson, Lennart (1978), “Att studera omvärldsuppfattning: Två bidrag till metodologin" [Studying perceptions of the outer world: Two contributions to the methodology] . Rapport från Pedagogiska institutionen, Göteborgs Universitet, no. 158, 1978.

Menken, Kate and Sanchez, Maite, T. (2019), "Translanguaging in English-Only Schools: From Pedagogy to Stance in the Disruption of Monolingual Policies and Practices", TESOL Quarterly, Vol. 53, No. 3: 741-767.

Reath Warren, Anne (2017), Developing Multilingual Literacies in Sweden and Australia: Opportunities and Challenges in Mother Tongue Instruction and Multilingual Study Guidance in Sweden and Community Language Education in Australia. PhD diss. Stockholm: Stockholms Universitet.

Schader, Basil (2012), Sprachenvielfalt als Chance [Multilingualism as an opportunity]. Zürich: Orell Füssli Verlag.

Schleppegrell, Mary J. (2004), The Language of Schooling: A Functional Linguistics Perspektive. Mahwah, New Jersey: Lawrence Erlbaum.

Svensson, Gudrun (2017), Transspråkande i praktik och teori. [Translanguaging in practice and theory] Stockholm: Natur och Kultur.

Svensson, Gudrun \& Torpsten, Ann-Christin (2017), "Transspråkande för förstärkt tvåspråkighet" [Translanguaging for stronger bilingualism], in Åsa Wedin (ed.), Språklig mångfald $i$ klassrummet. Stockholm: Lärarförlaget, pp. 37-60.

Torpsten, Ann-Christin \& Svensson, Gudrun (2017), "Jag tycker det är bra med translanguaging." [I think translanguaging is good], in Åsa Wedin (ed.), Språklig mångfald i klassrummet. Stockholm: Lärarförlaget, pp. 61-88.

Williams, Cen (1994), Arfarniad o ddulliau dysgu ac addysgu yng nghyd-destun addysg uwchradd ddwyieithog, $\mathrm{PhD}$ thesis. University of Wales, Bangor.

Williams, Cen (1996), "Secondary education: Teaching in the bilingual situation", in Cen Williams, Gwyn Lewis \& Colin Baker (eds), The Language Policy: Taking Stock. Llangefni: Community Associations Institute, pp. 39-7 